NBER WORKING PAPER SERIES

ECONOMIC GROWTH AND THE RISE

OF SERVICE EMPLOYMENT

Victor R. Fuchs

Working Paper No. $\underline{486}$

NATIONAL BUREAU OF ECONOMIC RESEARCH

1050 Massachusetts Avenue

Cambridge MA 02138

June 1980

\begin{abstract}
Helpful comments on this research by the participants in the Stanford University Labor Workshop are gratefully acknowledged. I would also like to thank Nick Dyer and Phillip Farrell for research assistance, Claire Gilchrist for secretarial assistance, and the NBER for financial assistance. The research reported here is part of the NBER's research program in Labor Economics. Any opinions expressed are those of the author and not those of the National Bureau of Economic Research.
\end{abstract}


ECONOMIC GROWTH AND THE RISE OF SERVICE EMPLOYMENT

\section{ABSTRACT}

The distribution of employment among Agriculture, Industry, and Service within countries is closely related to the level of real Gross Domestic Product per capita. As real income rises, Agriculture's share falls, Service employment rises, and Industry's share rises to a peak at about $\$ 3,300$ (1970 do1lars) per capita and then declines. U.S. time series and OECD cross-sections follow almost identical patterns of employment change. The decline of Agriculture is attributable primarily to differences in income elasticity of demand but the shift from Industry to Service is attributable primarily to differential rates of growth of output per worker. Economic growth also contributes to the rise of service employment through an increase in female labor force participation because families with working wives tend to spend a higher proportion of their income on services. Productivity tends to grow less rapidly in the Service sector than in the rest of the economy, but the shift of employment to Services was not a major factor in the slowing of aggregate productivity in the United States in the 1970's.

Victor R. Fuchs

National Bureau of Economic Research 204 Junipero Serra Boulevard

Stanford, California 94305

415/326-7160 


\title{
ECONOMIC GROWTH AND THE RISE OF SERVICE EMPLOYMENT
}

\author{
Victor R. Fuchs
}

Stanford University and National Bureau of Economic Research

\section{$\underline{\text { Introduction }}$}

Interest among economists in the interaction between economic growth and the industrial distribution of employment goes back more than forty years to the seminal work of Allan G. B. Fisher (1935) and Colin Clark (1940). "The most important concomitant of economic progress," wrote Clark, is "the movement of labor from agriculture to manufacture, and from manufacture to commerce and services." This prediction, it must be stated at the outset, is not derived from economic theory. Changes in the distribution of employment across industries are primarily the result of differences in income elasticities of demand for different goods and services and differences in rates of growth of labor productivity. Such differences may exist, but there is nothing in economic theory that tells us that they will, or that when they do the differences will be systematic and predictable.

Clark's generalization, as well as the findings to be discussed in this paper, should be viewed as descriptions of empirical regularities, not tests of theoretically grounded hypotheses. They are, nevertheless, of considerable interest. They do throw light on the growth process as

${ }^{*}$ Helpful comments on this research by the participants in the Stanford University Labor Workshop are gratefully acknowledged. I would also like to thank Nick Dyer and Phillip Farrell for research assistance, Claire Gilchrist for secretarial assistance, and the NBER for financial assistance. The research reported here is part of the NBER's research in Labor Economics. Any opinions expressed are those of the author and not those of the National Bureau of Economic Research. 
it has in fact evolved. Given the robustness of the regularities, they do permit private and public decisionmakers to anticipate shifts in employment. And they may help us understand the extent to which shifts in the distribution of employment can feed back on the growth process itself.

A National Bureau of Economic Research project on the U.S. service industries (Fuchs 1968, Fuchs 1969) provided substantial confirmation of Clark's observation up to 1965, and also explored the reasons for the inter-sectoral shifts in employment. Investigators in other countries reported similar patterns (Ofer 1967a, Lengellé 1966, Worton 1969, Deakin and George 1965), although there is clearly some variation. The USSR experience, for instance, shows that the rate of growth of services can be altered by public policy. The Soviets seem to have made a deliberate effort to favor employment in manufacturing and to hold back the development of trade and services (ofer 1967b). $1 /$ In Latin America, by contrast, it is my impression that the increase of employment in trade and services has outpaced overall economic growth, possibly as an unintended consequence of relatively high wages in manufacturing and other policies which accelerated migration from rural to urban areas.

In this paper I bring up to date a broad overview of the U.S. experience and compare that experience with the pattern of development in the OECD countries. A new functional form for relating employment shares by sector to Gross Domestic Product is presented and its predictive accuracy assessed. I then examine one possible intervening variable between economic growth and the rise of service employment, namely an increase in female labor force participation. Expenditure data from a

$1 /$ Another way of interpreting the USSR experience is to say that the time of the consumer has been substituted for measured employment in retail trade. 
U.S. household survey are used to estimate the effects of a wife's participation in the labor market on the demand for services vs. goods. The paper concludes with a discussion of some possible effects of the rise of service employment on economic growth.

The sector definitions used in this paper are the same as those I used in The Service Economy: "Agriculture" includes farming, forestry and fishing; "Industry" includes mining, construction, transportation, communications, and public utilities, as well as manufacturing; "Service" includes all other industries, most notably trade; finance, insurance, and real estate; professional, personal, business, and repair services; and government (except those government enterprises which carry on activities similar to those covered in "Industry"). $1 /$ This classification, which is admittedly arbitrary, is similar to the one employed by Simon Kuznets in Modern Economic Growth (1966) and has been used by other investigators as well. The most questionable decision, the placement of transportation, communication, and public utilities in "Industry" rather than "Service," had very little impact on any of the conclusions for the United States.

The measurement of real output in the Service sector is, of course, notoriously weak because of difficulties in evaluating quality change and because substantial portions of the output are not sold in conventional markets. In my judgment, however, the most important conclusions regarding Service-Industry differentials are not attributable to biases in measurement. While growth of output in some branches of Service is probably understated in the official accounts (e.g., government services, banking) there are

I/A three-fold classification into Agriculture, Industry and Service is traditional. The rapid expansion of Service, however, suggests that disaggregation of that sector is highly desirable, although beyond the scope of this paper. 
other industries, such as retail trade, where the rate of growth of output is probably overstated (see Schwartzman 1969 in Fuchs 1969). Furthermore, there are significant portions of Industry where the official measures of real output are probably significantly biased (e.g., computer manufacturing, airplane manufacturing, construction).

Another measurement problem involves international comparisons of Gross Domestic Product at a point in time. In this paper I use the results of Irving Kravis and his colleagues (1978) to convert GDP estimates in own currency into U.S. dollar equivalents by actual comparison of prices. Such conversions undoubtedly come closer to the purchasing power parity concept than do the official exchange rates. I have, however, checked my results against those obtained using official exchange rates and the qualitative conclusions regarding the relationship between economic growth and sector employment shares are not sensitive to choice of conversion method.

Gross Domestic Product and sector shares of employment

Table 1 presents the distribution of employment by sector in the United States since 1870 and shows its relation to per capita GDP (in 1970 U.S. dollars). This relation is partially confounded by cyclical fluctuations (Industry's share of employment decreases during recessions) and by historical shifts in international trade patterns. Nonetheless, the dramatic fall of Agriculture, the rise and then fall of Industry, and the steady rise of Service employment is clearly discernible.

To be sure, the shifts revealed in Table 1 could be the result of historical changes in technology or tastes which happen to be correlated with the trend in real GDP per capita. An examination of inter-country 
Table 1. Gross Domestic Product and sector shares of civilian employment: U.S. 1870-1978.

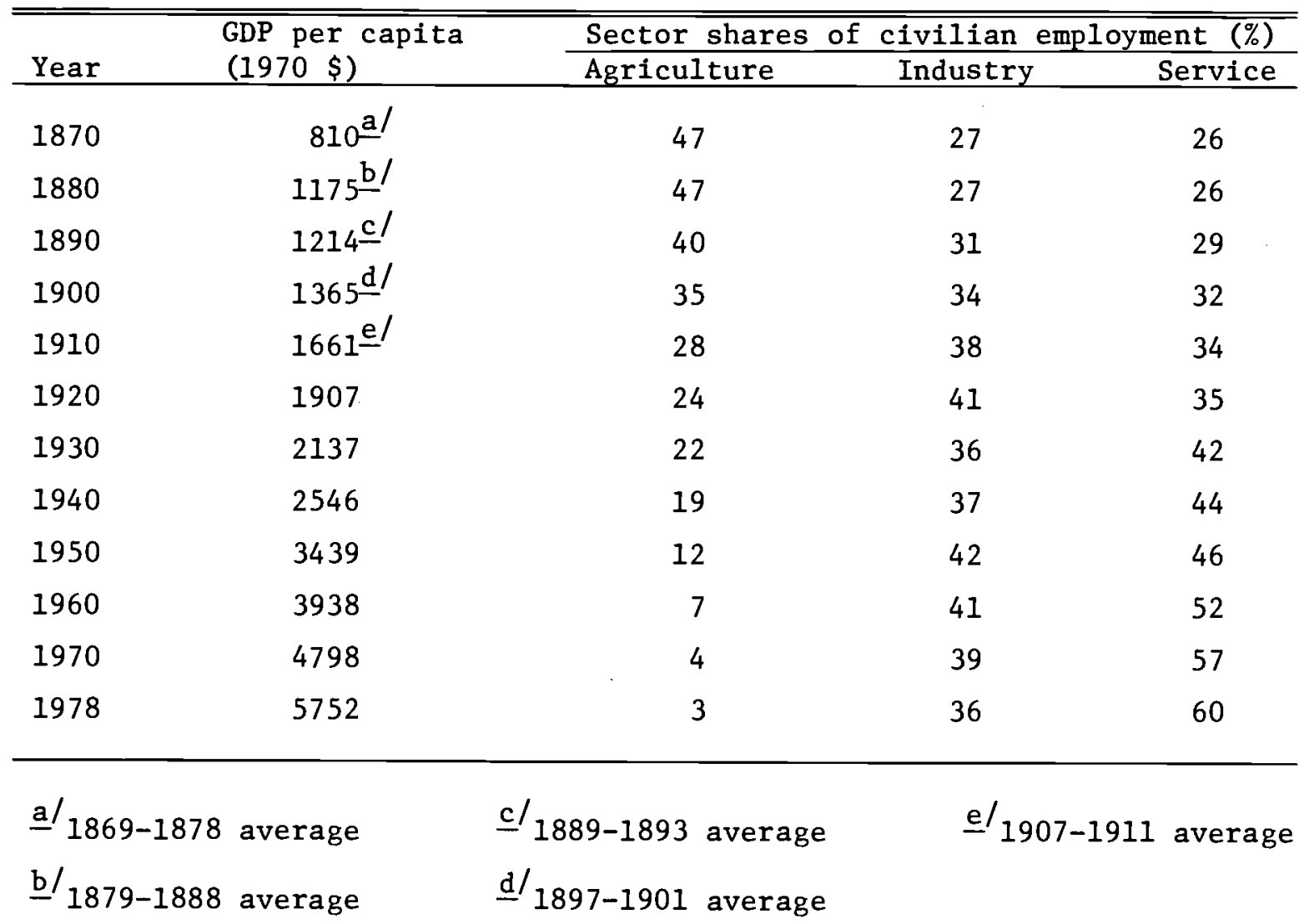

\section{Sources:}

GDP: 1870-1960 (in 1929 \$) from Historical Statistics of the U.S., 1970, Series F125.

1970 and 1978 are from Economic Report of the President, 1980, Table B-9.

All amounts converted to 1970 prices using GDP implicit price deflator (from Economic Report of the President, Table B-4).

Resident Historical Statistics of the U.S. 1970, Series A-7,

Population: for 1870-1970 (July 1 estimate).

Statistical Abstract of the U.S., 1978, Table 2, (April 1 estimate).

Civilian employment by sector:

1870-1930 Victor R. Fuchs, The Service Economy, NBER 1968, General Series No. 87, Table 4, Variant 2.

1940-1960 U.S. Bureau of the Census, U.S. Census of Population: 1960, Part 1, United States Summary, November 1963, Table 92.

1970 U.S. Bureau of the Census, 1970 Census of Population, Detailed Characteristics, U.S. Summary, Final Report PC(1)-D1, February 1973, Table 232.

1978 U.S. Bureau of Labor Statistics, Employment and Earnings, May 1978, Vol. 25, No. 5. 
differences at a fixed point in time provides an alternative view of the relation between economic growth and the distribution of employment. Table 2 shows the cross-section relation between GDP per capita and sector employment shares in OECD countries in 1970. The general pattern seems roughly similar to that of the U.S. historical experience; the extent of the similarity and the nature of the differences are explored through regression analysis.

In order to develop a realistic, estimable form that relates each sector's share of employment to the level of GDP, I assume that:

1) Agriculture's share is 1.0 at zero GDP per capita and approaches zero asymptotically as GDP rises: $A=e^{\beta\left(G D P^{\alpha}\right)}$.

2) Service's share is zero at zero GDP per capita and approaches 1.0 asymptotically as GDP rises: $\quad S=1-e^{\delta\left(G D P^{\gamma}\right)}$.

These equations were transformed to logarithms and estimated as a system using a maximum likelihood iterative procedure: $\underline{\text { I' }}$

$$
\operatorname{Ln} A=B_{G D P}^{\alpha} \quad \text { and } \operatorname{Ln}(1-S)=\delta G D P^{\gamma} .
$$

Inasmuch as Industry's share equals one minus the shares of Agriculture and Service by definition, the Industry equation is obtained as the residual:

$$
I=e^{\delta\left(G D P^{\gamma}\right)}-e^{\beta\left(G D P^{\alpha}\right)} .
$$

These regressions were run for the U.S. historical data and for OECD cross-sections in 1960, 1970, and 1976. For the OECD countries in 1970, GDP per capita in 1970 U.S. dollars was obtained from Kravis et al. using the International Comparison Project direct estimates for eight countries and Kravis et $\underline{\text { al. }}$. indirect estimates for the remainder. Real GDP per capita in 1960 (or 1976) was estimated in U.S. 1970 dollars by fixing the 1970 purchasing power parity estimate as the base and

I/ I am grateful to Bronwyn Hall for suggesting this general form and to Phillip Farrell for working out the details of the estimation. 
Table 2. Gross Domestic Product per capita (1970 U.S. dollars) and sector shares of civilian employment: OECD countries, 1970.

\begin{tabular}{|c|c|c|c|c|c|}
\hline \multirow{2}{*}{$\begin{array}{l}\text { Country } \\
\text { (in ascending } \\
\text { order of } \\
\text { "real" GDP) }\end{array}$} & \multirow{2}{*}{\multicolumn{2}{|c|}{ 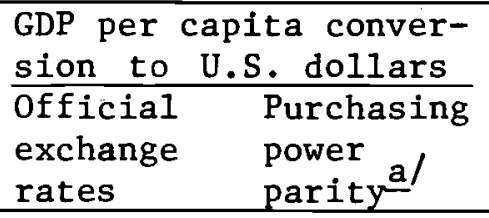 }} & \multicolumn{3}{|c|}{$\begin{array}{l}\text { Sector shares of civilian } \\
\text { employment (percent) }\end{array}$} \\
\hline & & & Agriculture & Industry & Service \\
\hline Turkey & 365 & 881 & 70 & 16 & 13 \\
\hline Portugal & 709 & 1298 & 30 & 38 & 33 \\
\hline Greece & 1135 & 1854 & 39 & 33 & 28 \\
\hline Spain & 1087 & 1902 & 30 & 42 & 28 \\
\hline Ireland & 1336 & 2041 & 27 & 36 & 37 \\
\hline Italy & 1720 & 2357 & 20 & 45 & 35 \\
\hline Austria & 1930 & 2496 & 19 & 47 & 35 \\
\hline Japan & 1906 & 2836 & 17 & 42 & 40 \\
\hline Finland & 2251 & 3022 & 23 & 43 & 35 \\
\hline United Kingdom & 2189 & 3042 & 3 & 52 & 45 \\
\hline New Zealand & 2237 & 3094 & 13 & 47 & 40 \\
\hline Iceland & 2424 & 3219 & 18 & 45 & 36 \\
\hline Norway & 2874 & 3276 & 14 & 48 & 38 \\
\hline Netherlands & 2433 & 3291 & 7 & 45 & 48 \\
\hline Australia & 2946 & 3334 & 8 & 47 & 45 \\
\hline Belgium & 2639 & 3449 & 5 & 50 & 46 \\
\hline Switzerland & 3195 & 3468 & 9 & 54 & 38 \\
\hline France & 2788 & 3506 & 14 & 46 & 40 \\
\hline Denmark & 3157 & 3516 & 11 & 44 & 45 \\
\hline West Germany & 3070 & 3746 & 9 & 55 & 36 \\
\hline Luxembourg & 3137 & 3846 & 9 & 52 & 39 \\
\hline Canada & 3885 & 3923 & 8 & 39 & 54 \\
\hline Sweden & 4110 & 4148 & 8 & 45 & 47 \\
\hline United States & 4790 & 4790 & 5 & 40 & 55 \\
\hline MEAN & 2430 & 3014 & 17.3 & 43.7 & 39.0 \\
\hline
\end{tabular}

a/ Measured real GDP/capita based on direct price comparisons [Kravis et al., 1978, Table 1] for Italy, Japan, United Kingdom, Netherlands, Belgium, France, Germany, and United States. Other countries: indirect estimates of real GDP/capita [Kravis et al., Table 4, Series D, except Luxembourg, Series C].

\section{Sources:}

GDP per capita: Kravis, Heston, and Summers, "Real GDP per capita for More Than One Hundred Countries," The Economic Journal, Vol. 88, No. 350, June 1978, Tables 1 and 4.

Civilian Employment by Sector: OECD "Labor Force Statistics, 1966-1977," Paris 1979, Country Tables III.

1971 data for Greece.

Armed forces included in service sector for Japan, Austria, Greece, Portugal and Sweden.

Transportation subsector estimated from closest available year for Denmark, Italy, Luxembourg, and Turkey. 
extrapolating back to 1960 (or forward to 1976) using each country's own estimated rate of change of real GDP per capita.

The results, presented in Table 3, show similar parameter values for all four sets of estimates. $1 /$ Moreover, as shown in Table 4, the correlation between the shares predicted by the regressions and the actual shares is very high in all cases (the median coefficient is .88). Indeed, the coefficients of correlation between cross-predictions (using equations estimated from other series) and actual values are, on average, about as high as the coefficients between the predicted and actual shares of the same series.

The similarity of the patterns and the goodness of fit are also revealed in the graphs of the U.S. and 1970 OECD equations presented in Figure 1. The curves for Agriculture are virtually identical. The curves for Industry and those for Service also reveal a close correspondence in the shape of the U.S. time series and the OECD cross-section, but there is a noticeable difference in levels. At any given level of real GDP per capita, the U.S. has had a larger fraction of employment in Service and a smaller fraction in Industry than have the other OECD countries. This may be explained by differences in composition of exports, with Industry playing a larger role in the other OECD countries and Agriculture playing a larger role in the U.S. It is particularly interesting to note that both the U.S. and the OECD equations predict a peak in Industry's share of employment at approximately the same level of real GDP per capita--somewhere between $\$ 3,000$ and $\$ 3,500$ in 1970 dollars.

Inspection of the actual shares (also plotted on Figure 1) shows that most observations fall very close to the estimated curves. For the U.S. time series, the median residual (absolute) is approximately .01 in each sector. As might be expected, 1930 and 1940 both show negative residuals for Industry $(-.03)$ because of the Depression.

If For the three OECD sets of regressions, a test based on the difference in the logarithms of the likelihood functions indicates that the nul1 hypothesis of no difference among the three years cannot be rejected, even at a $p$ of .5 . 
Table 3. Regression results: sector shares of civilian employment as function of Gross Domestic Product per capita, U.S. time series and $\mathrm{OECD}$ cross-sections.

\begin{tabular}{|c|c|c|c|c|c|}
\hline & & $\begin{array}{c}\text { U.S. } \\
1870-1978\end{array}$ & $\begin{array}{l}\text { OECD } \\
1960\end{array}$ & $\begin{array}{l}\text { OECD } \\
1970\end{array}$ & $\begin{array}{l}\text { OECD } \\
1976\end{array}$ \\
\hline $\mathrm{N}$ & & 12 & 23 & 24 & 23 \\
\hline \multirow[t]{2}{*}{ Agriculture } & B & $\begin{array}{l}-.787 \\
(.044)\end{array}$ & $\begin{array}{c}-.895 \\
(.131)\end{array}$ & $\begin{array}{l}-.716 \\
(.147)\end{array}$ & $\begin{array}{l}-.722 \\
(.158)\end{array}$ \\
\hline & $\alpha$ & $\begin{array}{l}.861 \\
(.040)\end{array}$ & $\begin{array}{l}.831 \\
(.159)\end{array}$ & $\begin{array}{l}.945 \\
(.166)\end{array}$ & $\begin{array}{l}.904 \\
(.158)\end{array}$ \\
\hline \multirow[t]{2}{*}{ Service } & $\delta$ & $\begin{array}{l}-.306 \\
(.011)\end{array}$ & $\begin{array}{c}-.263 \\
(.028)\end{array}$ & $\begin{array}{l}-.232 \\
(.033)\end{array}$ & $\begin{array}{l}-.242 \\
(.037)\end{array}$ \\
\hline & $\gamma$ & $\begin{array}{l}.633 \\
(.028)\end{array}$ & $\begin{array}{l}.634 \\
(.119)\end{array}$ & $\begin{array}{l}.714 \\
(.118)\end{array}$ & $\begin{array}{l}.720 \\
(.113)\end{array}$ \\
\hline
\end{tabular}

Equations: $\quad A=e^{\beta\left(G D P^{\alpha}\right)}$

$$
S=1-e^{\delta\left(G D P^{\gamma}\right)}
$$

Note: Standard errors in parentheses. GDP per capita in U.S. 1970 thousands of dollars. Currency conversions based on direct price comparisons for 1970. 
Table 4. Coefficients of correlation between actual and predicted sector shares of employment, U.S. time series and OECD cross-sections.

\begin{tabular}{lllll}
\hline \hline Predicted share, & \multicolumn{5}{c}{ Actual share } \\
\cline { 2 - 6 } based on:
\end{tabular}

\section{Agriculture}

U.S. $1870-1978$

OECD 1960

OECD 1970

OECD 1976
.986

.984

.986

.986
.891

.893

.890

.890

Industry

U.S. $1870-1978$

.900

OECD 1960

OECD 1970

OECD 1976
.886

.902

.901
.832

.836

.830

.832
.924

.948

.926

.952

.949

.947

\section{Service}

U.S. $1870-1978$

.987

.796

.842

.871

OECD 1960

.987

.796

.842

.870

OECD 1970

.987

OECD 1976

.987

.796

.842

.869

.796

.842

.869 


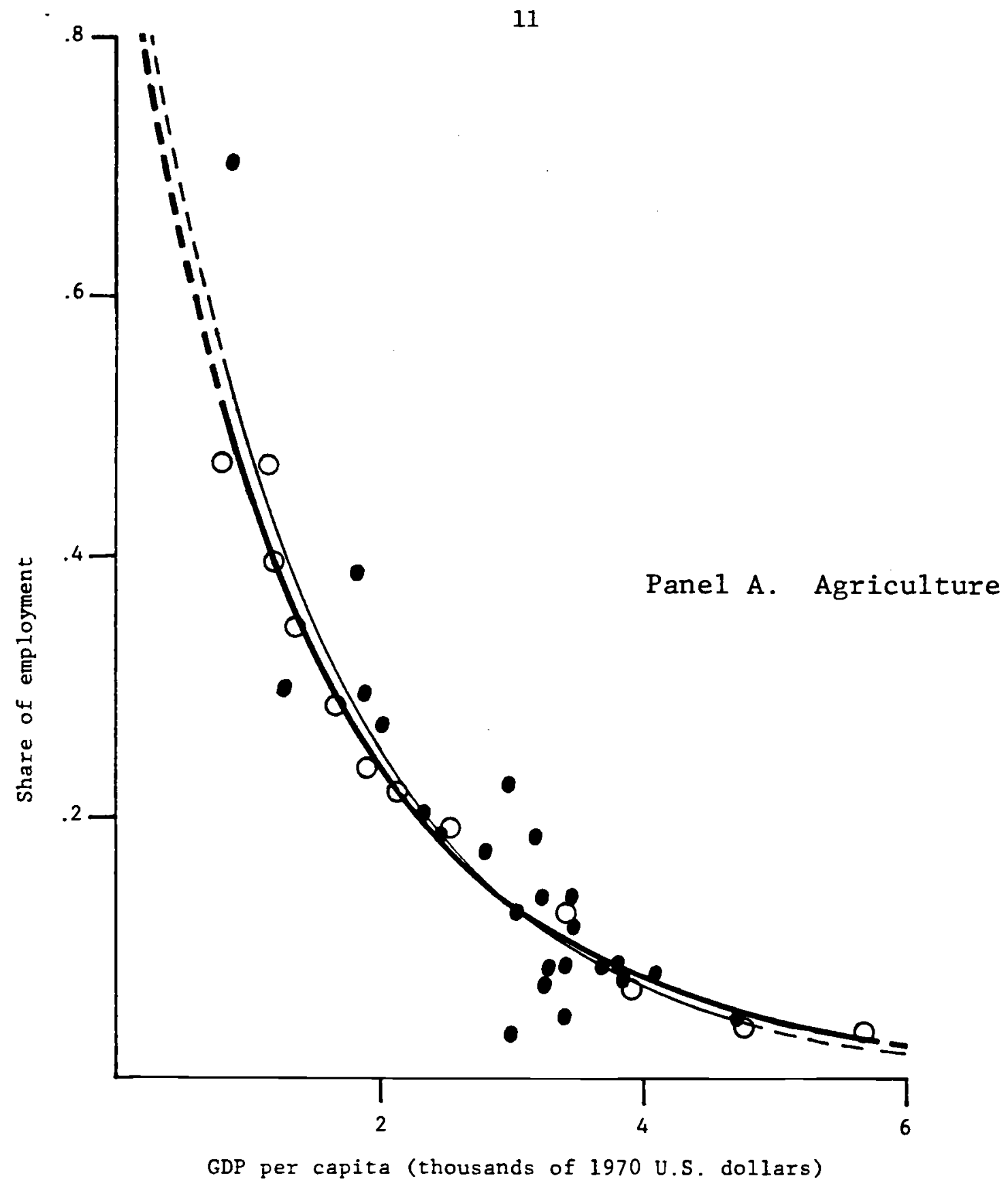

Figure 1. Sector shares of civilian employment vs. real GDP per capita, U.S. time series 1870-1798 and OECD cross-section 1970.

Legend:

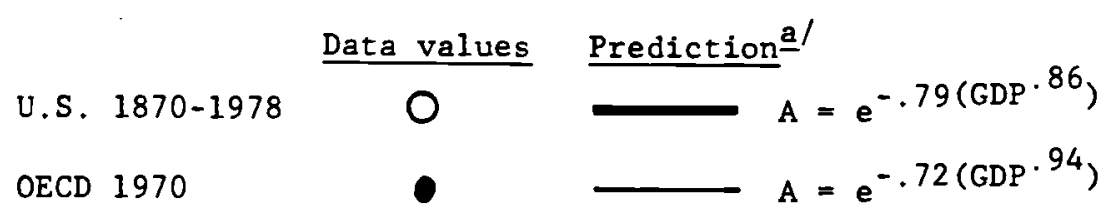

al Solid lines show observed range of GDP/capita; dashed lines show extrapolations. 


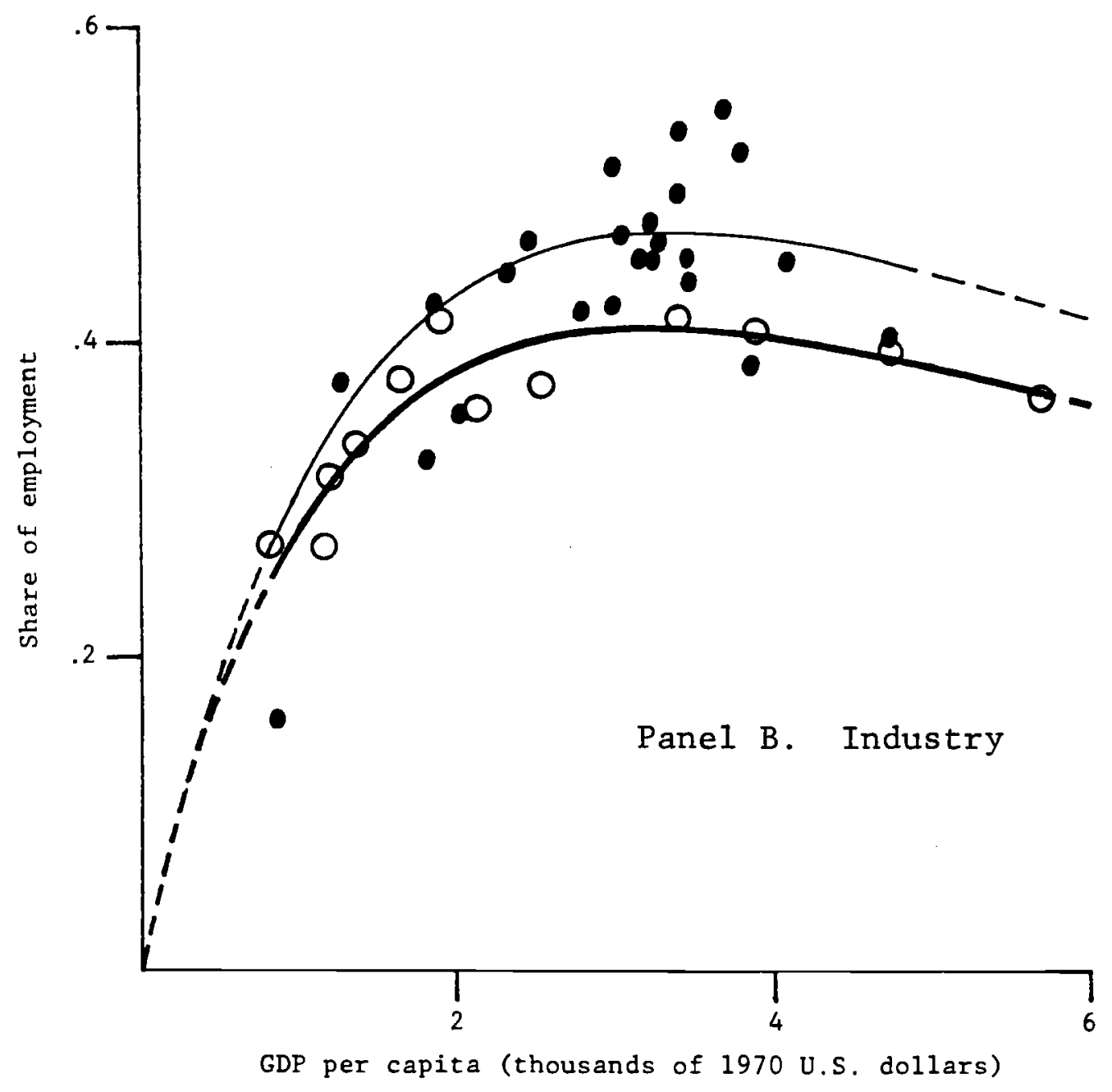

Figure 1, continued

Legend:

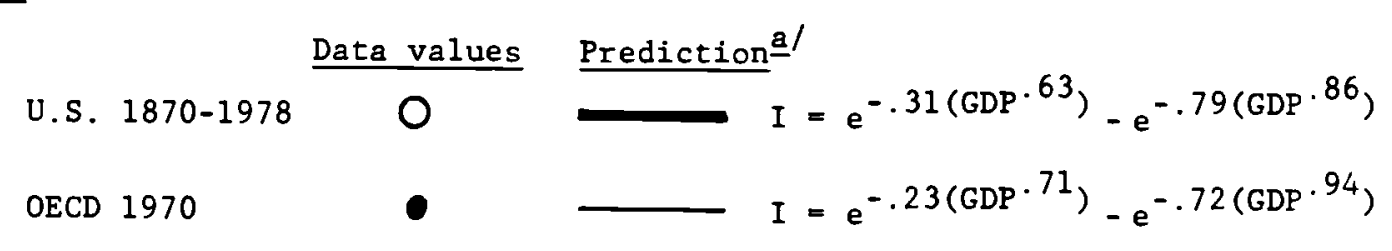

a/ Solid lines show observed range of GDP/capita; dashed lines show extrapolations. 


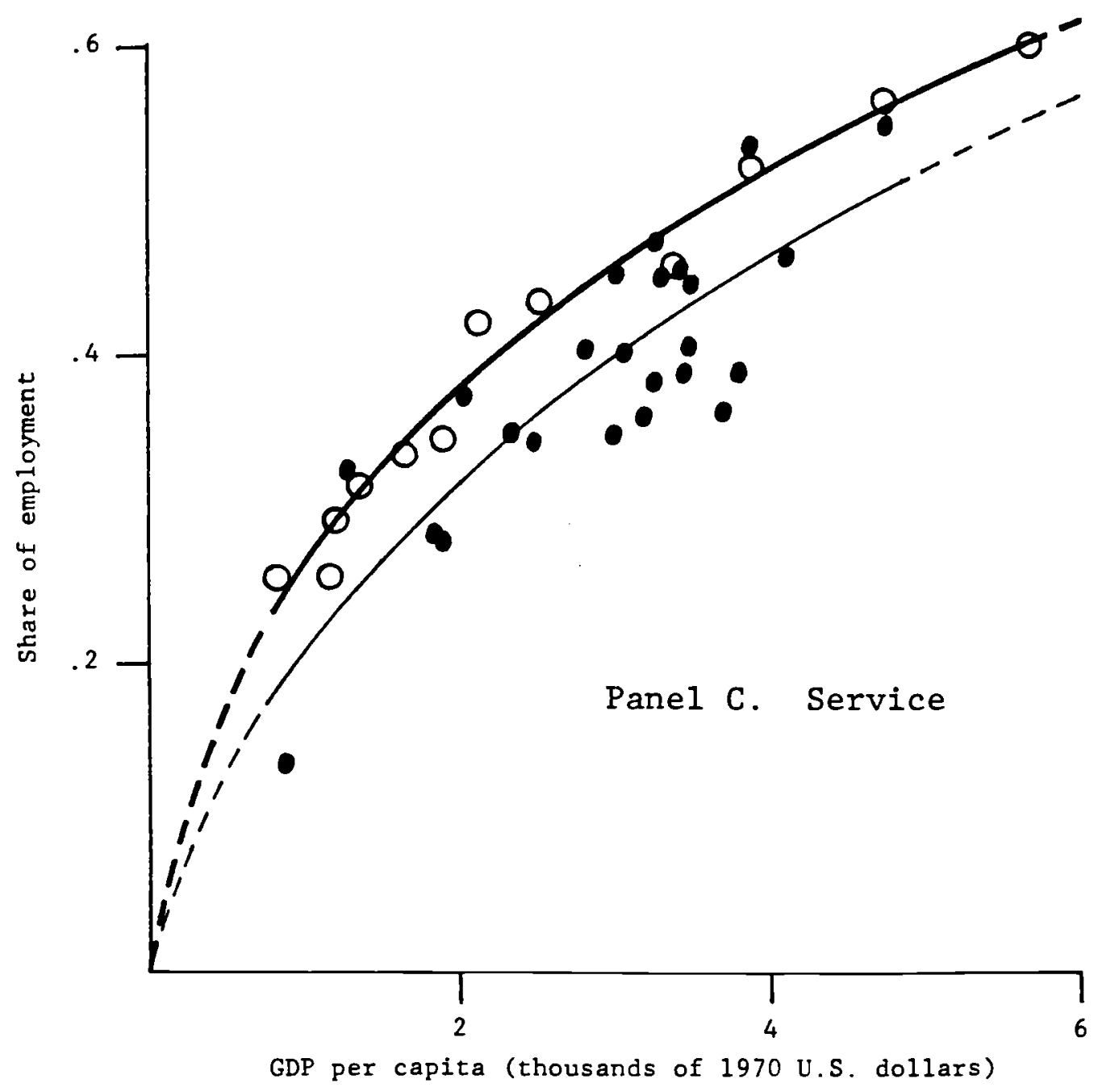

Figure 1, concluded

Legend:

Data values Prediction ${ }^{\text {a' }}$

U.S. $1870-1978 \quad 0$
OECD 1970

a/Solid lines show observed range of GDP/capita; dashed lines show extrapolations. 
For the OECD series the median residuals (absolute) are: Agriculture .03 , Industry .03 , and Service .04 . Most countries conform well to the predictions, but there are a few notably large residuals, some of which are also observed in 1960 and 1976 (not plotted). Turkey and Greece consistently have a larger than predicted share of employment in Agriculture and have large negative residuals in Industry. This may be related to the employment of many Greek and Turkish nationals in other OECD countries. The U.K. shows a large negative residual in Agriculture in 1960 and 1976 as well as 1970. The U.K. had a large positive residual in Industry in 1960; this was smaller in 1970 and had virtually disappeared in 1976. West Germany shows an interesting pattern with substantially more employment in Industry in 1970 and 1976 than would be expected given its real GDP per capita. This excess is exactly offset by a negative residual in Service. The growth of industrial exports by Germany may account for some of this pattern.

One of the most demanding tests of an alleged economic relationship is to see how well a cross-section regression predicts change over time. Another test is to see if a time-series regression for one period in one country predicts changes in other countries over a different time period. By this standard, the functions portrayed in Figure $I$ stand up rather well (see Table 5). The actual changes in sector shares in the OECD countries between 1960 and 1976 are positively correlated with predicted changes based on either the 1970 OECD regression or the U.S. 1870-1978 regression.

The correlation coefficient between actual and predicted change is much lower for Service than for Industry or Agriculture, but this seems to be because the variance in change is small. Between 1960 and 1976 every country showed an increase in the share of employment in Service; the mean change was .12 , but the standard deviation was only .04 . Despite 
Table 5. Correlation coefficients and residuals of actual and predicted changes in sector shares of employment in OECD countries, 1960 to 1976 .

\begin{tabular}{lccc}
\hline \hline & Agriculture & Industry & Service \\
\hline & & & \\
$\begin{array}{l}\text { Coefficient of correlation } \\
\text { between actual change and } \\
\text { predicted change, based on: }\end{array}$ & & & \\
OECD 1970 regression & .760 & .786 & .356 \\
U.S. 1870-1978 regression & .757 & .785 & .324 \\
Median change (absolute) & .09 & .05 & .12 \\
Median residual (absolute) & .04 & .06 & .02 \\
\hline
\end{tabular}

$\underline{a} /$ Absolute residual $=\left|\left(\mathrm{x}_{76}-\mathrm{x}_{60}\right)-\left(\hat{\mathrm{x}}_{76}-\hat{\mathrm{x}}_{60}\right)\right|$ where $\mathrm{X}=$ actual sector share, and $\hat{\mathrm{X}}=$ share predicted by 1970 OECD regression . 
the large change in the Service share in most countries, the difference between the actual and predicted change (median absolute residual) was less than .02 for half the countries and only two countries had absolute residuals larger than .06 .

Although the correlation coefficient for Industry is higher than for Service, the median absolute residual is actually higher also. During the period 1960-76 many of the OECD countries were at levels of GDP per capita that put them on the flat portion of the Industry employment share curve. For those countries, changes in that share between 1960 and 1976 were affected relatively more by cyclical phenomena and country-specific transitory factors in either 1960 or 1976 than by movement along the long-run function.

Reasons for the rise of service employment in the U.S. since 1948

The rise of Service employment in the course of economic growth is certainly beyond question, but the reasons for the correlation are more difficult to establish. Fisher and Clark both emphasized sector differences in income elasticities of demand, and this view is also held by many current writers (e.g., Richard Caves (1980)). I believe the emphasis on differential income elasticities is correct if one thinks of the expansion of the Service sector as part of the growth of nonagricultural output relative to Agriculture. At higher levels of GDP per capita, however, the principal phenomenon to be explained is the growth of Service employment relative to Industry. $\underline{-}$ This differential, in my judgment, is due more to differential trends in labor productivity than to differences in income elasticities, at least in the United States.

I/Agriculture becomes a much smaller and less important part of the employment story. 
Consider the measures in Table 6 which show sector rates of change (and levels) of employment, output, and productivity in the U.S. from 1948 to 1978. We see that the rate of growth of employment in the Service sector exceeded that in Industry by 1.55 percentage points per annum. By contrast, the differential in the rate of growth of output (GDP in 1972 dollars) was only .40 percentage points per annum. Thus, in a purely statistical sense the largest part of the differential trend in employment is attributable to the differential trend in output per worker ( 1.15 percentage points per annum). 1 / To be sure, the differential trend in real GDP may understate the effects of sector differences in income elasticities somewhat because the rise in the relative price of Service output probably deflected some demand to Industry. On the other hand, some of the growth of real GDP in the Service sector does not represent any real addition in service activity, but is attributable to a shift of services formerly produced within Industry to separate identifiable firms classified in the Service sector.

It is important to note that not all of the differential in rate of change of output per worker can be regarded as a pure productivity differential. The sector difference in trends of output per unit of total factor input is estimated from the trends in GDP in constant dollars relative to GDP in current dollars as follows:

$$
\Pi_{s}=\left(O_{s}-G_{s}\right)-\left(O_{t}-G_{t}\right)
$$

where $\Pi$ = relative total factor productivity;

$0=$ GDP in constant dollars;

$\mathrm{G}=\mathrm{GDP}$ in current dollars;

$\mathrm{s}=\operatorname{sector} \underline{\mathrm{s}}$;

$t=$ total economy

and all variables are rates of change.

It follows that $\Pi_{S V C}-\Pi_{I N D}=\left(0_{S V C}-G_{S V C}\right)-\left(0_{I N D}-G_{I N D}\right)$.

$1 /$ These differentials have been fairly stable throughout the post-World War II period, except for predictable changes associated with cyclical fluctuations and periods of military conflict. 
Table 6. Rates of change of employment, output and productivity in the United States, 1948-78 (percent per annum).

\begin{tabular}{lccccc}
\hline \hline & Agriculture & Industry & Service & $\begin{array}{l}\text { Service } \\
\text { minus } \\
\text { Industry }\end{array}$ & $\begin{array}{l}\text { Total } \\
\text { economy }\end{array}$ \\
& & & & & \\
Actual rates & & & & & \\
(1) Employment- & & +.76 & +2.31 & +1.55 & +1.40 \\
(2) GDP (1972 \$) & -2.11 & +3.37 & +3.77 & +.40 & +3.51 \\
(3) GDP (current \$) & +1.08 & +6.60 & +7.73 & +1.13 & +7.00 \\
(4) Output per worker (2) - (1) & +3.40 & +2.61 & +1.46 & -1.15 & +2.11
\end{tabular}

Rates relative to total economy

(5) Output per worker

(6) Output per unit of total factor input
$+1.08$

$+1.17$
$+.50$

$+.26$

$$
-.65
$$

$-.47$

$-1.15$

$-.73$
28.0

250.0

113.8
60.7

485.9

257.9
28.0

24.0

121.3$$
113.8
$$

$\begin{array}{rr}26.1 & 28.0 \\ 209.3 & 250.0 \\ 121.3 & 113.8\end{array}$

\section{8 levels}

Employment (millions)

GDP 1972 \$ (billions)

GDP 1978 \$ (billions)
3.5

38.7

66.6
32.8

574.7

879.6
56.0

774.2

1157.5
92.3

1391.1

2107.0

a/ Total estimated separately and GDP may not exactly equal sum of sectors.

b/Persons engaged, full-time equivalents.

c/ Derived from the differential rates of change of GDP in constant and current dollars. (See text for explanation.) 
This is a reasonable approximation unless the prices of factors of production change at substantially different rates in Industry and Service, or unless relative factor prices change substantially and there are marked differences in factor proportions in the two sectors.

The total factor productivity differential between Service and Industry is only .73 percent per annum, indicating that part of the reason for the large differential trend in output per worker (and for the growth of Service employment) is the more rapid growth of other inputs (physical and human capital) in Industry. This has occurred at a rate of .42 percent per annum $(1.15-.73)$, and this conclusion is independent of possible errors in measuring constant dollar GDP in either sector.

This result suggests several interesting questions for research. Have other OECD countries experienced a similar pattern in recent decades? Is the faster growth of capital per worker in Industry in the U.S. attributable to non-neutral technological change, or to the greater amount of unionization in Industry than in Service, or to other factors? Another interesting research question is to identify the sources of the .73 percent per annum "pure" productivity differential, e.g. economies of scale or technological progress.

Female labor force participation and the demand for services

In the U.S. data for 1870-1978, both real GDP per capita and the service sector's share of total employment are highly correlated with the female labor force participation rate. ${ }^{\prime}$ One possible connection is that the growth of Service employment induces a rise in female labor force

\footnotetext{
$1 /$ This correlation is not observed in the OECD cross-section
} data. 
participation by expanding job opportunities in industries which have traditionally been heavily female. Between 1950 and 1970 almost one-half of the female-male differential in the rate of growth of employment is attributable to changes in industry mix rather than to an increase in the female share of employment in each industry (Fuchs 1978).

A causal connection which runs from real GDP per capita to female labor force participation is also plausible. Gary Becker (1965) and Jacob Mincer (1962) have argued that economic growth tends to raise the value of women's time in the labor market relative to the value of time at home, thus inducing more women to participate in paid work. In recent decades in the U.S. the increase in female labor force participation has been notable among married women with spouse present and most notable among those who have young children at home (see Table 7).

When a wife enters paid employment, the household's demand for goods and services may change differentially for two principal reasons. First, the household will typically have more money income and income elasticities of demand may differ. Second, the household may reallocate expenditures because the wife now has less time for production in the home or because she demands a different mix of commodities in connection with her work. For instance, the household with a working wife may allocate a larger share of expenditures to restaurant meals or to domestic servants, or the wife may purchase an automobile in order to get to work.

To explore the possible differential impact of rising female labor force participation on the demand for goods and services, a statistical experiment was performed on data from the U.S. Bureau of Labor Statistics Consumer Expenditure Survey 1972-73. $1 /$ In order to increase the homogeneity

1'I am grateful to Robert Michael for making this data set available to me, and for his advice concerning the effects of demographic variables on consumer demand. 
Table 7. Female labor force participation by family status, the United States, selected years 1950 to 1978 (percent participating).

\begin{tabular}{lcccc}
\hline \hline & 1950 & 1960 & 1970 & 1978 \\
\hline Al1 females--all ages & 33.9 & 37.7 & 43.3 & 50.0 \\
All females--age 35-44 & 39.1 & 43.4 & 51.1 & 61.3 \\
Married, spouse present & 23.8 & 30.5 & 40.8 & 47.6 \\
$\begin{array}{l}\text { Married, spouse present, } \\
\text { with children age 6 to 17 only }\end{array}$ & 28.3 & 39.0 & 49.2 & 57.2 \\
$\begin{array}{l}\text { Married, spouse present, } \\
\text { with children under 6 }\end{array}$ & 11.9 & 18.6 & 30.3 & 41.6 \\
\hline
\end{tabular}

Source: U.S. Department of Labor, 1979 Employment and Training Report of the President. 
of the sample, the analysis was restricted to white, home-owning households consisting of a wife, an employed husband, and one or two children under the age of $18(\mathrm{~N}=829)$. Unfortunately, it is not possible with these data to make a consistent match between consumer expenditure classes and the sector classifications previously discussed (based on employment and Gross Domestic Product). I try to achieve rough comparability by grouping expenditures into "goods," "services," and "other." "Goods" consist of food, alcohol, and tobacco consumed at home; clothing; vehicles and transportation; and all other durables. "Services" consists of food and alcohol consumed away from home; vacations; domestic servants, laundry and dry cleaning; and out-of-pocket expenditures for health and education. "Other" is equal to the household's after-tax income minus "goods" and "services." It includes saving, home mortgage payments, real estate taxes, life insurance premiums, and a variety of miscellaneous goods and services, such as heating fuel, telephone, and electricity.

To determine the effect ${ }^{1 /}$ of a wife working on the share of expenditures going to goods or services, the logarithm of the expenditure share is regressed on a dummy variable "wife working full time" (compared with wife not working at all) plus a large number of other variables introduced to control for other factors that might affect expenditure shares. These are: age of husband, education of husband, education of wife, number and age of children, region of country, size of city, and the logarithm of total expenditures. In one set of regressions total expenditures are equal to goods plus services plus other. In the other set, the total is only the

$1 /$ This model assumes that causality runs from the employment status of wife to expenditure patterns, not the reverse. To the extent that the reverse causality is true, the coefficient of the wife's work status variable may be biased. I am grateful to Thomas MaCurdy for discussion of this point. 
sum of goods and services. The dependent variable is always the logarithm of the share of total expenditures in a particular class (i.e., goods, services or other).

The regression coefficient of the wife working variable shows the difference between households with wife working full time and those with wife not working in the share of total expenditures spent for the designated class of commodities. Because the dependent variable is the logarithm of the share, the coefficient indicates the percent differential. For example, a coefficient of -.04 for goods in the first regression (Table 8 ) indicates that in households with wife working the share of goods in total expenditures is four percent less than in households with wife not working.

Three regressions were run for each class in each set. In the first, no other independent variables were included. In the second, all the other variables except the log of total expenditures were included; this variable was added in the third. Thus the third shows the reallocative effect net of possible differential income elasticity effects.

Table 8 indicates that the effect of a wife working on expenditure shares is different for goods than for services and the difference is statistically significant at $p<.01$. This result holds regardless of which other variables are included and regardless of how "total expenditures" is specified. I/ The share of expenditures going to services seems to rise by about 10 percent as a result of a wife going to work. (I.e., if the share in a household with wife not working is .30 , it would be .33 in a similar household with a working wife.) The share going to goods seems to fall by about three or four percent. The fact that the coefficients are very similar regardless of whether the logarithm of total expenditures is held constant

$1 /$ The consistency of results is also observed in more complex specifications (not shown) which allow for possible interactions between wife's work status and income. 
Table 8. Regressions of logarithm of expenditure shares on employment status of wife and other variables, a cross-section of U.S. households, ${ }^{2}$ 1972-73 ( $\left.=829\right)$.

\begin{tabular}{|c|c|c|c|c|c|}
\hline \multirow{2}{*}{$\begin{array}{l}\text { Regression } \\
\text { number }\end{array}$} & \multirow{2}{*}{$\begin{array}{l}\text { Dependent } \\
\text { variable }\end{array}$} & \multirow{2}{*}{$\begin{array}{l}\text { Other independ- } \\
\text { ent variables }\end{array}$} & \multicolumn{3}{|c|}{$\begin{array}{l}\text { Regression coefficient of wife work- } \\
\text { ing full time vs. wife not working } \\
\text { (Standard errors of regression } \\
\text { coefficients in parentheses) }\end{array}$} \\
\hline & & & Goods & Services & Other \\
\hline 1 & $\begin{array}{l}\text { Ln of share } \\
\text { of "total" } \\
\text { expenditures } c /\end{array}$ & None & $\begin{array}{l}-.042 \\
(.034)\end{array}$ & $\begin{array}{l}+.093 \\
(.045)\end{array}$ & $\begin{array}{l}+.063 \\
(.051)\end{array}$ \\
\hline 2 & $"$ & $\begin{array}{l}\text { All except Ln "total" } \\
\text { expendituresc/ }\end{array}$ & $\begin{array}{l}-.040 \\
(.034)\end{array}$ & $\begin{array}{l}+.093 \\
(.045)\end{array}$ & $\begin{array}{l}+.060 \\
(.052)\end{array}$ \\
\hline 3 & $"$ & All a $/$ & $\begin{array}{l}+.007 \\
(.033)\end{array}$ & $\begin{array}{l}+.113 \\
(.045)\end{array}$ & $\begin{array}{l}+.003 \\
(.051)\end{array}$ \\
\hline 4 & $\begin{array}{l}\text { Ln of share } \\
\text { of "total" } \\
\text { expenditures } \text { / }\end{array}$ & None & $\begin{array}{l}-.031 \\
(.011)\end{array}$ & $\begin{array}{l}+.104 \\
(.039)\end{array}$ & \\
\hline 5 & $"$ & $\begin{array}{l}\text { All except Ln /"total" } \\
\text { expenditures }\end{array}$ & $\begin{array}{l}-.030 \\
(.011)\end{array}$ & $\begin{array}{l}+.103 \\
(.038)\end{array}$ & \\
\hline 6 & $"$ & All & $\begin{array}{l}-.033 \\
(.011)\end{array}$ & $\begin{array}{l}+.109 \\
(.039)\end{array}$ & \\
\hline
\end{tabular}

a/ Other variables are age of head, education of head, education of wife, number and age of children, region of country, city size, and logarithm of total expenditures.

b/Limited to white, home-owning households with wife, employed husband, and one or two children under age 18 .

$c /$ Total expenditures $=$ Goods plus Services plus other.

d/ Total expenditures $=$ Goods plus Services. 
or not suggests that the difference in effect on goods and services is primarily due to reallocation rather than to differential income elasticities.

If we take these results at face value, the reallocative effect of a wife going to work is approximately .1. Thus, an increase in the female labor force participation rate of one percentage point per year (the U.S. experience since 1950 has come close to that rate of change) would imply a shift of demand toward services of approximately .I percent per annum. This is about one-fourth of the .4 percent per annum shift in the service sector's share of real GDP shown in Table 6 .

This experiment can hardly be regarded as definitive, but it does suggest that in the U.S. the increase in female labor force participation may have made a small contribution to the rise of service employment through a reallocation of expenditures by households toward services.

Effects of the rise of service employment on economic growth

At the present time there seems to be more interest in the consequences of the rise in Service employment on economic growth than in explanations of why growth shifts employment to Services. This interest is undoubtedly triggered by the slowdown in aggregate productivity growth in the United States and other countries, and the desire to attribute the slowdown to some one or some thing. Because productivity rises more slowly in Service than in Industry, some observers take it as self-evident that the growth of the Service sector's share of employment must be a major factor in the productivity malaise of the 1970's. A healthy skepticism about such a facile explanation, however, is clearly in order. After all, the shift to Service employment was every bit as strong during the earlier post-war decades when aggregate productivity was rising rapidly. 
Serious analysis must begin by noting that changes in the sector distribution of employment can change the aggregate productivity trend only through level effects, rate effects, and the interaction between these effects. Level effects can be significant if the sectors differ substantially in the level of productivity in the base year and if there are substantial shifts in sector shares of constant dollar GDP over time. A classic example of the level effect is the shift in constant dollar GDP from Agriculture (a sector with relatively low base year productivity) to Industry and Service. This shift undoubtedly contributed to aggregate productivity growth in the United States and in other countries as well. The rate effect depends on sector differences in rates of growth of productivity and on a shift in input shares between sectors. $1 /$ Thus the decline in the share of employment in Agriculture (a sector with particularly rapid productivity growth in the U.S.) has tended to slow down the change in aggregate productivity.

Given the relatively small share of Agriculture in the U.S. economy in the 1970's (measured either in employment or GDP), it is most fruitful to concentrate on the Industry-Service differential in order to determine the extent to which the shift to Service employment can explain changes in aggregate productivity trends. Michael Grossman and I explored this question in considerable detail with a series of simulations under a variety of assumptions about sector levels and rates of change in productivity (Grossman and Fuchs 1973). Given reasonable parameter values, based on U.S. experience, we found that the growth of the Service sector relative to Industry could account for only small changes in productivity trends even over a fifty-year period. The principal reason is that the distribution of

$1 /$ To simplify, the following discussion will assume that there is only one input--"employment." The conclusion would not be materially altered by consideration of multiple inputs. 
constant dollar GDP between Industry and Service has not changed much in the last three decades (see Table 6); thus the level effect must be small. If, for simplicity, we assume constant shares of real GDP, the rate of change in aggregate productivity is a weighted average of the rates of change in the two sectors where the weights are employment shares in the terminal year, i.e.

$$
\mathrm{R}_{\mathrm{T}}=\mathrm{mR}_{\mathrm{S}}+(1-\mathrm{m}) \mathrm{R}_{\mathrm{I}}
$$

where $R=$ rate of change of productivity;

$\mathrm{m}=$ the Service sector's share of total employment (i.e., Industry plus Service);

$\mathrm{S}=$ Service;

$I$ = Industry;

$T=$ total.

The effect of the shift to Service then, is the change in weights multiplied by the differential in the rates. We see in Table 6 that the Industry-Service differential in rate of change of labor productivity is 1.15 percent per annum, and of total factor productivity, .73 percent per annum. The change in the Service sector's employment share of Industry plus Service is from .52 in 1948 to .63 in $1978.1 /$ Roughly speaking, we have a one percent per annum differential in rate multiplied by a .1 change in weight. This implies a slowing down of aggregate productivity growth in the U.S. of approximately .1 percent per annum between 1948 and 1978 as a result of the rise of Service employment. Inasmuch as the slowdown in aggregate productivity growth is at least one percent per annum, we see that the growth of the Service sector cannot be a major explanatory factor.

$1 /$ The Service share of Industry plus Service total input increased from .48 to .57 . 
A few additional points about U.S. growth in recent decades are worth noting. The rapid increase in female labor force participation since the end of World War II has tended to raise the rate of growth of measured real GDP per capita because the ratio of working to total population has risen. To the extent that women are now producing less in nonmarket activities (not included in GDP), this is a spurious growth of total economic output. Another effect of the rise in female labor force participation is to lower the rate of growth of output per worker, but this too is spurious because it reflects a change in labor force mix rather than a slowdown in productivity for given workers. Finally, even if both the above effects of rising female labor force participation have been operative in the U.S., they can scarcely be a source of any significant change in the rate of change because female labor force participation has been rising rapidly throughout the post-World War II era. 
REFERENCES

Becker, Gary S., "A Theory of the Allocation of Time," Economic Journal, Vol. 75, No. 299, September 1965.

Caves, Richard, "The Structure of Industry," in Martin S. Feldstein (ed.), Postwar Changes in the American Economy, NBER conference volume, University of Chicago Press, Chicago, 1980 forthcoming.

Clark, Colin, The Conditions of Economic Progress, Macmillan, London, 1940.

Deakin, B. M. and K. D. George, Productivity Trends in the Service Industries, 1948-63, Cambridge, England, 1965.

Fisher, Allan G. B., The Clash of Progress and Security, London, 1935.

Fuchs, Victor R. (assisted by Irving Leveson), The Service Economy, National Bureau of Economic Research, New York, 1968.

Fuchs, Victor R. (ed.), Production and Productivity in the Service Industries, Conference on Research in Income and Wealth, Vol. 34, National Bureau of Economic Research, New York, 1969.

Fuchs, Victor R., "The Service Industries and U.S. Economic Growth Since World War II," in Jules Backman (ed.), Economic Growth or Stagnation?, Bobbs-Merril1, Indianapolis, 1978.

Grossman, Michael, and Victor R. Fuchs, "Intersectoral Shifts and Aggregate Productivity Change," Annals of Economic and Social Measurement, 2/3, 1973 .

Kravis, I. B., A. Heston and R. Summers, "Real GDP per Capita for More Than One Hundred Countries," The Economic Journal, Vol. 88, No. 350, June 1978.

Kuznets, Simon, Modern Economic Growth, New Haven and London, 1966.

Lengellé, Maurice, La Revolution Tertiaire, Editions Genin, Paris, 1966.

Mincer, Jacob, "Labor Force Participation of Married Women," in Aspects of Labor Economics (no editor), Princeton, Princeton University Press, 1962.

Ofer, Gur, Service Industries in a Developing Economy, New York, 1967a.

Ofer, Gur, "The Service Sector in the Soviet Union," unpublished Ph.D. dissertation, Harvard University, 1967b.

Schwartzman, David, "The Growth of Sales Per Man-Hour in Retail Trade, 1929-63," in Victor R. Fuchs (ed.), Production and Productivity in the Service Industries, Conference on Research in Income and Wealth, No. 34, National Bureau of Economic Research, New York, 1969. 
U.S. Bureau of Labor Statistics, Survey of Consumer Expenditures, 1972-73, Government Printing Office, Washington, D.C.

Worton, David A., "The Service Industries in Canada, 1946-66," in Victor R. Fuchs (ed.), Production and Productivity in the Service Industries, Conference on Research in Income and Wealth, Vol. 34, National Bureau of Economic Research, New York, 1969. 